\title{
The impact of corporate governance on firm competitiveness and performance of small and medium enterprises in South Africa: A case of small and medium enterprises in Vanderbijlpark
}

\begin{tabular}{|c|c|}
\hline \multicolumn{2}{|c|}{$\begin{array}{l}\text { Authors: } \\
\text { Progress Hove-Sibanda }{ }^{1} \\
\text { Kin Sibanda }{ }^{2} \\
\text { David Pooe }^{3}\end{array}$} \\
\hline \multicolumn{2}{|c|}{$\begin{array}{l}\text { Affiliations: } \\
{ }^{1} \text { Department of Transport } \\
\text { Economics and Logistics } \\
\text { Management, North West } \\
\text { University, South Africa }\end{array}$} \\
\hline \multicolumn{2}{|c|}{$\begin{array}{l}{ }^{2} \text { Department of Economics, } \\
\text { University of Fort Hare, } \\
\text { South Africa }\end{array}$} \\
\hline \multicolumn{2}{|c|}{$\begin{array}{l}{ }^{3} \text { Department of Business } \\
\text { Management, University of } \\
\text { Johannesburg, South Africa }\end{array}$} \\
\hline \multicolumn{2}{|c|}{$\begin{array}{l}\text { Corresponding author: } \\
\text { Progress Hove-Sibanda, } \\
\text { proggyhove@gmail.com }\end{array}$} \\
\hline \multicolumn{2}{|c|}{$\begin{array}{l}\text { Dates: } \\
\text { Received: } 23 \text { Oct. } 2016 \\
\text { Accepted: } 04 \text { July } 2017 \\
\text { Published: } 20 \text { Oct. } 2017\end{array}$} \\
\hline \multicolumn{2}{|c|}{$\begin{array}{l}\text { How to cite this article: } \\
\text { Hove-Sibanda, P., Sibanda, K. } \\
\text { \& Pooe, D., 2017, 'The impact } \\
\text { of corporate governance on } \\
\text { firm competitiveness and } \\
\text { performance of small and } \\
\text { medium enterprises in South } \\
\text { Africa: A case of small and } \\
\text { medium enterprises in } \\
\text { Vanderbijlpark', Acta } \\
\text { Commercii 17(1), a446. } \\
\text { https://doi.org/10.4102/ } \\
\text { ac.v17i1.446 }\end{array}$} \\
\hline \multicolumn{2}{|c|}{$\begin{array}{l}\text { Copyright: } \\
\text { (C) 2017. The Authors. } \\
\text { Licensee: AOSIS. This work } \\
\text { is licensed under the } \\
\text { Creative Commons } \\
\text { Attribution License. }\end{array}$} \\
\hline \multicolumn{2}{|l|}{ Read onli } \\
\hline 口ixp & $\begin{array}{l}\text { Scan this QR } \\
\text { code with your } \\
\text { smart phone or } \\
\text { mobile device } \\
\text { to read online. }\end{array}$ \\
\hline
\end{tabular}

Orientation: Corporate governance adoption and compliance are an issue augmenting in importance recently and have been extended to business enterprises of any size including small and medium enterprises (SMEs).

Research purpose: This study seeks to examine the impact of corporate governance adoption on the firm competitiveness and performance of SMEs in Vanderbijlpark.

Research design, approach and method: The study employs a cross-sectional research design, which employed quantitative methods. One hundred fifty-two SME owners or managers were selected from Vanderbijlpark in Gauteng, South Africa. The collected data were analysed using a structural equation modelling system by using Smart PLS software.

Main findings: The principal findings of this study revealed that the implementation of corporate governance by SMEs significantly and positively affected their competitiveness and performance.

Practical and managerial implications: The paper provided practical implications and made some recommendations.

Contribution or value-added: This article bridges the gap between theory and practice because it has both an economic and commercial impact in practice. It can be used in influencing public policy, teaching and research (because it contributes to the body of knowledge, particularly regarding SME corporate governance in emerging markets). An important aspect of this article is that it gives a framework for additional similar studies in other locations within emerging markets to test the generalisability of the findings. For teaching purposes, it provides a template for how to assess the link that exists between corporate governance and SME performance. Lastly, the article gives a unique empirical analysis of the relationship that exists between corporate governance compliance and performance of firms in South Africa, and thereby giving a valid contribution to corporate governance literature.

\section{Introduction}

Corporate governance has often remained erroneously linked with the red tape barriers and agency problems that are left to large firms (Bates 2013). For the past decades (from 1994 when the first King Report was published, to 2003 when a revised edition of the King Report was released, till 2008 the period before the release of the King Report III), corporate governance is an issue that has been completely divorced from especially small and medium enterprises (SMEs), owing to the absence of the agency problem because the owners of these firms are the directors and managers and assume many other duties within the firm (Abor \& Biekpe 2007; Rossouw, van der Watt \& Malan-Rossouw 2002). However, in reality, as argued by Bates (2013), corporate governance in its practical application is an important key, which unlocks the true value of a business regardless of the firm size. Willan et al. (2016), whose study revealed that organisations whether large or small have the same benefits, influences and challenges when it comes to the application of corporate governance, confirmed this. In other words, corporate governance can shift the SME firm from a survivalist entity incapable of growing past the abilities of its owners, to being an enterprise with factual and sustainable growth through improved competitiveness, firm performance and value (Abor \& Biekpe 2007; Bates 2013). As such, the present-day global world has gradually been apprehensive with the application of corporate governance in SMEs, also owing to the vital developmental roles fulfilled by these SMEs in a number of economies. 
In South Africa, the government and other SME development agencies are making some efforts to encourage corporate governance compliance in SMEs. Some of these efforts include the release of the King Report III in 2009, as well as the King Report IV in 2016, which have some corporate governance principles and practices that accommodate SMEs. The major differences between the King Reports III and IV include the fact that the 75 principles in the King Report III have been summarised into 17 principles in the King Report IV. More so, the King Report IV gives a clear distinction between principles and practices with an aim to yield good corporate governance from all the principles in all the organisations regardless of their size. Lastly, the King Report IV has specific sections meant for SMEs and other unlisted entities, unlike the King Report III, which was rather general. However, the King Report III still remains the basis of corporate governance principles, while the King Report IV assumes the application or adoption of the corporate governance principles (King Report IV 2016). As such, the current study used the King Report III because it is deemed the basis of corporate governance principles instead of the King Report IV, which is more on application of these principles.

Some of these principles include: responsible and effective leadership; the ethical foundations of the business; risk response processes and monitoring by management and disclosure to stakeholders; integrating ethics, risks and opportunity profile; code of conduct; assessing, monitoring, reporting and disclosure; role and function of $\mathrm{CEO}$; performance assessment of the leader; director (leader) development; compliance with the codes, rules, laws and standards; leaders' understanding of the effect of compliance on the firm; governing stakeholder relationships; IT governance, the leader's responsibility, monitor IT investments, application of IT governance framework and expenditures as well as IT to form part of the firm's risk management (Le Roux 2010). In addition, a training institution, the Global Business School of Entrepreneurship, formed to offer both formal and informal training and increase corporate governance awareness in South African SMEs, is one of the efforts to promote corporate governance compliance in SMEs (CGF Research Institute 2013).

All such efforts to promote corporate governance adoption and compliance by SMEs are motivated by the fact that SMEs in developing nations, particularly in South Africa, are seen as primary employment creators and alleviators of poverty. In other words, the continued existence, expansion and sustained growth of SMEs in such emerging economies are crucial aspects of both public and political life (Hove \& Chikungwa 2013). Nevertheless, despite all government efforts to stimulate their growth, most SMEs in South Africa have been reported to be having a high failure rate especially in the first 2 years of operation (Olawale \& Garwe 2010). Neneh and Van Zyl (2012) report that, in 2011, 'the failure rate of SMEs in South Africa was 75\%'. The majority of SME failures have been associated with their inability to adopt or the nonexistence of good corporate governance, which limits their access to financial resources needed for their growth (Le
Roux 2010). The Global Entrepreneurship Monitor (GEM) (2015/16) reports that South African SMEs, which currently account for $98 \%$ of the firms in the country and in 2014 contributed about $45 \%$ towards the country's GDP, were counted among those SMEs with the highest proportions of exits (precisely, over one quarter) globally, as a result of lack of finance. This raises the question of whether these SMEs do conform to the principles and practices of good corporate governance. If they do apply these principles, how then does their compliance influence their firm competitiveness and performance? Why the high SME exit rates as indicated by the GEM report of 2015/16?

Corporate governance application in South African SMEs is an issue still in its infant stage, where most studies are still concerned with the compliance issues (Flowers et al. 2013). More so, there is little or no consideration at all given to the influence that corporate governance has on SMEs' competitiveness and performance particularly in the Gauteng Province. In reality, much literature has dwelt heavily on dominant firms because of the misapprehension that corporate governance is relevant for just the superior firms that struggle with the agency problem (Kim \& Lu 2013; Mangena \& Chamisa 2008; Molokwu, Barreria \& Urban 2013; Muniandy \& Hillier 2015; Ntim, Lindop \& Thomas 2013). Nevertheless, corporate governance might be of high significance also to the underrated SMEs, operated by a sole proprietor or owner who also acts as the manager and director (Ansong 2015). Promoting good corporate governance in SMEs could help South Africa strengthen its corporate governance opacity index rated low (at a score of 16), and its anticorruption index rated fairly weak (at a score of 40) in 2013 (Claessens \& Yurtoglu 2013). In the light of the above, this article, hence, attempts to examine the influence of corporate governance on SMEs' competitiveness and performance in Vanderbijlpark, Gauteng Province, South Africa. The remainder of the article comprises a literature review, research methodology, data analysis and results, conclusions and implications as well as the limitations of the study.

Figure 1 shows the posited linear relationships between the three research variables in this article. Corporate governance is the predictor variable, firm competitiveness is the mediator variable and firm performance is the outcome variable.

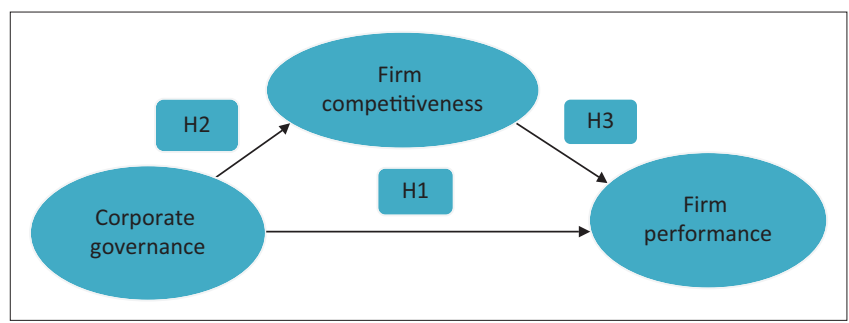

Source: Authors' own work

H1: Corporate governance positively influences SME firm performance. $\mathrm{H} 2$ : Corporate governance positively influences SME firm competitiveness. H3: Firm competitiveness positively influences SMEs' performance. FIGURE 1: Research conceptual framework. 


\section{Literature review}

The Resource-Based View is the theory used in this article to theoretically ground and explain how corporate governance affects firm competitiveness and performance of SMEs. The theory is premised on the assumption of considerable and continual firm heterogeneity in terms of resource endowments. It is commonly proposed that this heterogeneity emanates from inimitability and the inability of firms to alter their acquired stock of resources over time (De Wit \& Meyer 2005). The model holds that the core of the strategy is or should be defined by the unique resources and capabilities of a firm (Spanos \& Lioukas 2001). In addition, the theory argues that the importunate differences in firm performance require that either the product of a firm be differentiated, or that it attains a low cost position or focus leadership in relation to its competitors (Louw \& Venter 2010:245). In other words, the main argument of the Resource-Based View is that resources and capabilities determine how efficiently and effectively a firm functions and performs. It is worth noting that a given strategy will create a sustainable competitive advantage and performance differential if, and only if, the resources used to envisage and implement it are valuable, rare, inimitable and non-substitutable (Ehlers \& Lazenby 2007). In the light of the above, this article uses the ResourceBased View to explain good and effective adoption of corporate governance as a distinctive capability, which creates a competitive advantage and improves performance for the SMEs. The next section reviews the empirical evidence on the three research variables: corporate governance, firm competitiveness and firm performance.

\section{Corporate governance}

Corporate governance as defined by Abor and Biekpe (2007) is the process as well as a structure used to direct and manage the business affairs of a firm towards enhancing business prosperity and corporate accountability, with the ultimate goal of realising shareholder value. (p. 288). Abor and Biekpe (2007:288) also provided a definition of corporate governance in SMEs and referred to it as the respective roles of the shareholders who are the owners, managers, directors as well as other officers of the firm'. As noted earlier, the significance of corporate governance has been debated mostly within the setting of larger firms and outside Africa. For instance, Kim, Sung and Wei (2017) evaluated the two dimensions of investor heterogeneity and how corporate governance has diffused into emerging markets using Korean data. Fuenzalida et al. (2013) investigated whether or not good governance practices enhance or constrain returns on the Lima Stock Exchange using data from Peruvian firms. Arosa, Itturralde and Maseda (2013) examined the impact that the structure of the board has on firm performance using data collected from SMEs in Spain and established a negative effect of the outside director's proportion along with the board size on firm performance.

In Africa, Ngobo and Fouda (2012) examined the connection between good corporate governance and the profitability of
African enterprises. Hearn (2011) investigated the influence of corporate governance measures on the performance of West African IPO firms. A study by Munisi, Hermes and Randoy (2014) focused on examining the relationship between board and ownership structure for firms listed on the stock exchanges of 12 sub-Saharan African countries. As such, little empirical evidence exists on this area with regard to SMEs in Africa.

Of the little empirical evidence that exist, noted examples include a study by Abor and Biekpe (2007), which assessed the adoption of corporate governance structures and how these influence the performance of SMEs in Ghana. Using the regression analysis, their findings revealed that corporate governance structures (foreign ownership, CEO duality, board composition, family business, inside ownership and board size) have a significant positive impact on performance (profitability) of SMEs in Ghana. Also conducted in Ghana is the study by Ansong (2015) which explored the effects of board size and level of board participation on SMEs' financial performance. The study established that the size of the board and financial performance do have a progressive connectedness, while the level of board participation had no relationship with financial performance.

In South Africa, Flowers et al. (2013) explored corporate governance practices in small and micro-fast moving consumer goods enterprises in Cape Metropole, Western Cape Province. Their findings showed that $36 \%$ of the SME owners or managers showed some good comprehension of what entails corporate governance, while $64 \%$ of them were ignorant of the meaning of corporate governance.

Le Roux (2010) investigated the applicability of the King Report III, regarded as the leading authority as far as corporate governance is concerned within South Africa, to SMEs. The findings of the study revealed that most of the King Report III corporate governance principles apply to SMEs. The corporate governance principles found applicable to SMEs in Le Roux's study were adopted as measures for corporate governance in this article. In view of the ResourceBased View that explains the corporate governance as a distinct capability of a firm, as well as the aforementioned empirical evidence, this article hypothesises that the adoption and compliance with the King Report III corporate governance principles applicable to SMEs positively influences firm performance of SMEs in Vanderbijlpark, Gauteng Province, South Africa. This is stated as:

H1: Corporate governance positively influences SME firm performance.

\section{Firm competitiveness}

Firm competitiveness in this article denotes the capability of a business enterprise to outwit its competitors based on particular competitive advantages that accumulate to the enterprise through either minimised costs or maximised business opportunities. According to Maniak (2006), firm 
competitiveness is determined by a specific behaviour of a firm. For a firm to attain competitiveness in the market, it is essential that the firm first achieves a competitive advantage, which refers to the firm's doing its activities better or differently from its competitors (Maniak 2006). There are numerous ways to gain competitiveness obtainable for firms. This study describes corporate governance as one of the sources for firm competitive advantage. It contends that the adoption and effective compliance with corporate governance principles by entrepreneurs may create a distinctive capability for the SMEs, minimise the general costs of the small enterprises, enable them to acquire a competitive advantage over their competition and enhance their firm competitiveness. Consequently, this study posits that:

H2: Corporate governance positively influences SME firm competitiveness.

\section{Small and medium enterprises' firm performance}

Firm performance indicates how the amassed technologyenabled performance influences in each of the firm activities, for instance revenue enhancement cost reduction, and competitiveness (Melville, Kraemer \& Gurbaxani 2004). Vorhies and Morgan (2005) support that, in spite of the overall acceptance that robust firm capability improves firm performance, voluminous indefiniteness is existent on the measurement of enterprise performance. A number of articles including Homburg and Pflesser (2003), Hooley et al. (2005) and Wong and Merrilees (2007) have actually focused on measuring firm marketing performance, which represents but a proportion of the aggregate performance of the business. Nonetheless, in this study firm performance is measured utilising the balanced score card, which combines all aspects of firm performance. According to Pienaar and Vogt (2012) a balanced score card by design ensures a balance between financial and non-financial performance. Badenhorst-Weiss, Biljon and Ambe (2017) in support add that 'a balanced score card recognises that performance measurement should include more than just financial measures and adds three key performance indicators: customers, business processes along with innovation and learning'. As such this study also recognises that SME firm performance goes beyond the financial aspects (profitability) and that these financial measures need to be supplemented with the customer, business processes, as well as innovation and learning measures. This provides a balanced view of SME firm performance. Hence, for the purposes of the current study, SME firm performance includes exportation, sales growth, profitability, employee satisfaction and retention, employee productivity, cost reduction, return on investment, customer satisfaction and retention, new product development and innovation and learning, in the light of the business-owners' evaluation of their enterprise relative to their competitors. Therefore, this study suggests the following:

H3: Firm competitiveness positively influences SMEs' performance.

\section{Research methodology}

Cant et al. (2003:65) explain a research methodology as a systematic and scientific criterion of making conclusions about an elaborate research problem. A descriptive analytical approach was used in this study because the fundamental relationships of research variables surrounding the problem were known (Cant et al. 2003). A quantitative research technique was employed in order to obtain SME owners' or managers' experiences of the how corporate governance actually influences their firm's competitiveness and performance in Vanderbijlpark.

\section{Sample and data collection}

A survey that employed self-administered questionnaires was conducted to collect data. The SME owners or managers whose businesses are located in Vanderbijlpark, who have been in operation for at least 2 years, and comply with the description of an SME provided by the National Small Business Act of 1996 were the respondents in this study. The Emfuleni Municipality authorities were approached to obtain the sampling frame which comprised a list of registered 1026 SMEs. Simple random probability sampling enabled researchers to draw a sample of 200 SMEs, which was obtained through the use of the Raosoft sample size calculator. From the 200 self-administered questionnaires issued, 152 questionnaires were usable for data analysis in this article. The self-administered questionnaires were designed to permit the application of the validity and reliability indices by using SMART PLS. This quantitative methodology, which performs structural equation modelling by using SMART PLS, is advantageous in the sense that the reliability and validity form part of the findings. More so, for sample data of less than 200, Smart PLS is known to produce robust results (Chinomona 2013).

\section{Measurement instrument and questionnaire design}

Measurement scales for the study were adopted from former studies. Appropriate changes were effected in order to make the scales relevant for the purpose and context of the present study. Fifteen items adapted from Le Roux (2010) were used to measure 'Corporate governance'. In measuring 'Firm competitiveness' 12 items were used, which were borrowed from a study by Sultan (2007). Finally yet importantly, 12 items also taken from Sultan (2007) and (Hove 2012) were used to measure 'Firm performance'. However, after the analysis by using SMART PLS, results show only 10 measures of firm performance, because exportation (FP1) and new product development (FP11) had factor loadings of less than 0.5. In other words, exportation and new product development explained less than $50 \%$ of firm performance, which led to them being deleted. All the items measuring the main variables to this study were aggregated on a five-point Likert scale described by the scores: 1 which represents strongly disagree up to 5 which represented the opposite extreme for respondents to indicate how far they agreed with the given scenarios or statements. 


\section{Sample demographics}

Table 1 depicts profiles of the small business proprietors surveyed during data collection. The participants were requested to provide information regarding their demographic data, including gender, age and education. In addition, some business profile information was obtained from the following: the time in years since commencement of operation, number of employees, average annual turnover and compliance with corporate governance. A majority of the respondents were males (53\%), while $47 \%$ were females; $56 \%$ of the SME owners were 30 years old and below, 30\% of the respondents were between 31 and 60 years old, whereas $14 \%$ were above 60 years of age; $66 \%$ of the SME owners or managers were holders of matric qualifications, $26 \%$ were holders of diploma or certificate qualifications and $8 \%$ held higher education degree or post-graduate degree certificate.

On the SME profiles, $65 \%$ of the SMEs had operated between 2 and 10 years, 30\% had lived between 11 and 20 years, while, $5 \%$ have operated for more than 20 years in business; $72 \%$ of these SMEs employ less than 50 workers, while $28 \%$ have between 50 and 200 workers. About $63 \%$ of the surveyed SMEs generate an average annual turnover of less than R1 million, 22\% generate between R1 million and 5 million, while $15 \%$ have a turnover of more than R 5 million per year. Lastly, the SME owners or managers were asked on whether their firms comply with corporate governance.

\begin{tabular}{|c|c|c|}
\hline Characteristics & Frequency & Percentage \\
\hline \multicolumn{3}{|l|}{ Demographic Profile } \\
\hline \multicolumn{3}{|l|}{ Gender } \\
\hline Male & 80 & 53 \\
\hline Female & 72 & 47 \\
\hline Total & 152 & 100 \\
\hline \multicolumn{3}{|l|}{ Age } \\
\hline$\leq 30$ & 85 & 56 \\
\hline $31-60$ & 45 & 30 \\
\hline$>60$ & 22 & 14 \\
\hline Total & 152 & 100 \\
\hline \multicolumn{3}{|l|}{ Education qualification } \\
\hline High school certificate & 100 & 66 \\
\hline Diploma or certificate & 40 & 26 \\
\hline Degree or post-grad. degree & 12 & 8 \\
\hline Total & 152 & 100 \\
\hline \multicolumn{3}{|l|}{ SME profile } \\
\hline \multicolumn{3}{|l|}{ Number of years in operation } \\
\hline $2-10$ years & 99 & 65 \\
\hline $11-20$ years & 41 & 30 \\
\hline Above 20 years & 12 & 5 \\
\hline Total & 152 & 100 \\
\hline \multicolumn{3}{|l|}{ Number of employees } \\
\hline Less than 50 & 110 & 72 \\
\hline $50-200$ & 42 & 28 \\
\hline Total & 152 & 100 \\
\hline \multicolumn{3}{|l|}{ Turnover } \\
\hline Less than 1 million & 95 & 63 \\
\hline 1 million-5 million & 34 & 22 \\
\hline Above 5 million & 23 & 15 \\
\hline Total & 100 & 100 \\
\hline
\end{tabular}

As shown in Table 2, 52\% of these SMEs are complying with some of the corporate governance principles while $48 \%$ are not. Six of the nine corporate governance principles were complied with, while no compliance was reported for internal audit, audit committee and external auditing, along with integrated reporting. Full or most compliance was reported for laws, codes and standards that meet SME needs, stakeholder management and having IT governance structures, while less compliance was reported for having a risk governance structure, as well as ethical leadership and corporate citizenship.

\section{Data analysis and results}

In order to make use of the structural equation modelling analytical technique in testing the main conjectured influence that corporate governance has on firm competitiveness and firm performance of SMEs, the researchers used the Smart PLS statistical software. According to Liljander, Polsa and van Riel (2009) a partial least squares (PLS) approach is defined as a structural equation model (SEM) approach that orients towards predictions and bases on variances as well as some suppositions concerning the variables' dispersion. Unlike the other traditional highest probability SEM methods, for example the LISREL (Joreskog \& Sorbom 2006) together with

TABLE 2: Compliance with corporate governance principles.

\begin{tabular}{|c|c|c|c|}
\hline Principles & Compliance & Frequency & Percentage \\
\hline \multicolumn{4}{|c|}{ Compliance with corporate governance: } \\
\hline & Yes & 79 & 52 \\
\hline & No & 73 & 48 \\
\hline & Total & 152 & 100 \\
\hline \multicolumn{4}{|c|}{ Corporate governance principles complied with: } \\
\hline \multicolumn{4}{|c|}{ Having a board of directors } \\
\hline & Yes & 33 & 42 \\
\hline & No & 46 & 58 \\
\hline & Total & 79 & 100 \\
\hline \multicolumn{4}{|c|}{ Comply with ethical leadership and corporate citizenship } \\
\hline & Yes & 19 & 24 \\
\hline & No & 60 & 76 \\
\hline & Total & 79 & 100 \\
\hline Have an au & ittee and external auditing & 0 & 0 \\
\hline \multicolumn{4}{|c|}{ Have a risk governance structure } \\
\hline & Yes & 3 & 4 \\
\hline & No & 76 & 96 \\
\hline & Total & 79 & 100 \\
\hline Comply wit & lauditing & 0 & 0 \\
\hline \multicolumn{4}{|c|}{ Comply with stakeholder management } \\
\hline & Yes & 66 & 84 \\
\hline & No & 13 & 16 \\
\hline & Total & 79 & 100 \\
\hline \multicolumn{4}{|c|}{ Have an IT governance structure } \\
\hline & Yes & 44 & 56 \\
\hline & No & 35 & 44 \\
\hline & Total & 79 & 100 \\
\hline Comply wit & ted reporting & 0 & 0 \\
\hline \multicolumn{4}{|c|}{$\begin{array}{l}\text { Compliance with laws, codes and standards that } \\
\text { meet SME needs }\end{array}$} \\
\hline & Yes & 79 & 100 \\
\hline & No & 0 & 0 \\
\hline & Total & 79 & 100 \\
\hline
\end{tabular}

Source: Authors' own work 
AMOS (Byrne 2001), Smart PLS needs moderately fewer observations. In that capacity, the smart partial Least squares software was deemed comparably applicable and relevant to the present research especially with a moderately small sample of 152 SME owners or managers who were interviewed.

\section{Measurement model}

\section{Reliability and validity}

Reliability as described by Iacobucci and Churchill (2010:258) is 'the similarity of results provided by the independent but comparable measures of the same object or construct, or an index of consistence'. The Cronbach's alpha and composite reliability (CR) values were the primary measures employed to test for reliability of the research variables in this study. Furthermore, convergent validity was tested by employing item or factor loadings of above 0.5 according to the corresponding variables (Chinomona 2013). The main measures of discriminant validity in this article were the average variance extracted (AVE) values and making sure there were no multiple collinearity problems between all the measures of the three latent variables (Chin 1998). The results obtained from the reliability and validity tests are shown in Table 3. A detailed explanation of the specific measures and the codes for firm performance is presented in Appendix 1 (Table 1-A1), and for corporate governance measures and codes see Appendix 1 (Table 2-A1).

As mentioned earlier, the study used CR and the $\alpha$ values in testing the reliability of the three research constructs. The CR values varied between 0.940 and 0.965 , while the $\alpha$ values varied from 0.929 to 0.961 as shown in Table 3. The obtained values from $\mathrm{CR}$ and $\alpha$ were above the acceptable reliability score of 0.7 , thus validating the internal consistency of the three research construct measures according to Nunnally and Bernstein (1994).

Convergent validity as previously noted was measured by examining if each factor loading for the respective construct

TABLE 3: Accuracy analysis statistics.

\begin{tabular}{|c|c|c|c|c|c|c|c|c|}
\hline \multicolumn{2}{|c|}{ Research construct } & \multirow[t]{2}{*}{ LV index value } & \multirow[t]{2}{*}{$R$-squared value } & \multirow[t]{2}{*}{ Cronbach's $\alpha$ value } & \multirow[t]{2}{*}{ CR value } & \multirow[t]{2}{*}{ AVE value } & \multirow[t]{2}{*}{ Communality } & \multirow[t]{2}{*}{ Factor loading } \\
\hline PLS code & PLS code item & & & & & & & \\
\hline \multirow[t]{13}{*}{ CG } & CG 1 & 3.239 & 0.000 & 0.961 & 0.965 & 0.653 & 0.653 & 0.619 \\
\hline & CG 2 & & & & & & & 0.886 \\
\hline & CG 3 & & & & & & & 0.874 \\
\hline & CG 4 & & & & & & & 0.916 \\
\hline & CG 5 & & & & & & & 0.891 \\
\hline & CG 7 & & & & & & & 0.876 \\
\hline & CG 8 & & & & & & & 0.709 \\
\hline & CG 9 & & & & & & & 0.845 \\
\hline & CG 10 & & & & & & & 0.704 \\
\hline & CG 11 & & & & & & & 0.794 \\
\hline & CG 12 & & & & & & & 0.827 \\
\hline & CG 13 & & & & & & & 0.765 \\
\hline & CG 15 & & & & & & & 0.758 \\
\hline \multirow[t]{12}{*}{$\mathrm{FC}$} & FC 1 & 3.217 & 0.667 & 0.930 & 0.940 & 0.570 & 0.570 & 0.789 \\
\hline & FC 2 & & & & & & & 0.824 \\
\hline & FC 3 & & & & & & & 0.796 \\
\hline & FC 4 & & & & & & & 0.699 \\
\hline & FC 5 & & & & & & & 0.800 \\
\hline & FC 6 & & & & & & & 0.826 \\
\hline & FC 7 & & & & & & & 0.768 \\
\hline & FC 8 & & & & & & & 0.788 \\
\hline & FC 9 & & & & & & & 0.529 \\
\hline & FC 10 & & & & & & & 0.796 \\
\hline & FC 11 & & & & & & & 0.682 \\
\hline & FC 12 & & & & & & & 0.755 \\
\hline \multirow[t]{8}{*}{ FP } & FP 2 & 3.400 & 0.658 & 0.929 & 0.942 & 0.623 & 0.623 & 0.764 \\
\hline & FP 5 & & & & & & & 0.887 \\
\hline & FP 6 & & & & & & & 0.847 \\
\hline & FP 7 & & & & & & & 0.838 \\
\hline & FP 8 & & & & & & & 0.816 \\
\hline & FP 9 & & & & & & & 0.724 \\
\hline & FP 10 & & & & & & & 0.624 \\
\hline & FP 12 & & & & & & & 0.503 \\
\hline
\end{tabular}

Source: Authors' own work

PLS, partial least squares; CG, corporate governance; FC, firm competitiveness; FP, firm performance. CR, composite reliability; AVE, average variance reliability. Scores: 1 - strongly disagree; 2 - disagree; 3 - neutral; 4 - agree; 5 - strongly agree. 
was over the minimal acceptable score of 0.5 (Anderson \& Gerbing 1988). As is depicted in Table 3, each of the three corresponding variables' factor loadings varied from 0.503 to 0.916 , which are evidently beyond the acceptable benchmark of 0.5 . Two items of firm performance (FP1 and FP11) were deleted as they had factor loadings of less than 0.5 , the recommended threshold. Therefore, to conclude, the bulk of the measures utilised to describe the three latent variables of this study justified above $50 \%$ of the variables of corporate governance, firm competitiveness as well as firm performance in SMEs.

In addition, as previously alluded, the presence of discriminant validity in the variable measures was evaluated with the use of AVE scores above 0.5 (Byrne 2001; Fornell \& Lacker 1981). As presented in Table 3, the entire AVE scores in this study varied between 0.570 and 0.653 . Nonetheless, in order to ensure adequate divergent validity among the latent variables, the square-rooted AVE values of each of the three variables were calculated, and as required they exceeded the associations between that latent variable and all other variables (Byrne 2001). In this article, the square roots of AVE varied between 0.755 and 0.808 , which therefore exceeded the correlations concerning the three research constructs, which varied from 0.75 to 0.801 (Table 4 ). This additionally

TABLE 4: Inter-construct correlation matrix.

\begin{tabular}{lccc}
\hline Research constructs & CG & FC & FP \\
\hline CG & 1.000 & - & - \\
FC & 0.801 & 1.000 & - \\
FP & 0.785 & 0.750 & 1.000 \\
\hline
\end{tabular}

Source: Authors' own work

$\mathrm{CG}$, corporate governance; $\mathrm{FC}$, firm competitiveness; FP, firm performance. proves the presence of divergent validity. In general, the values verify the reliability and validity of the latent variable measures utilised.

Smart PLS unlike the AMOS and LISREL software does not offer the goodness-of-fit measures for the full path model. Rather, the software simply gives the $R^{2}$ values for the dependent variables (firm competitiveness and performance in this article). Nevertheless, goodness-of-fit in this article has been determined by utilising a universal goodness-of-fit method, which according to Tenenhaus, Amato and Vinzi (2004) accounts for both the quality of measurement and the structural model. The following formula was used to calculate the global goodness-of-it:

$$
\begin{aligned}
\text { Goodness - of - fit } & =\sqrt[2]{\left(\text { average of all AVE values } * \text { average of all } R^{2}\right)} ; \\
& =\sqrt[2]{0.615 * 0.442} \\
& =0.522
\end{aligned}
$$

The resultant value using the formula is 0.522 and, as in accordance with Wetzels, Odekerken-Schröder and van Oppen (2009), it exceeds the commended mark of 0.36. A conclusion can thus be made that the research model gives a satisfactory and acceptable model fit. The next section presents Figure 2 and Table 5, which help in the discussion of the hypotheses testing results.

A confirmatory factor analysis (CFA) was employed in this article and the SEM was estimated by using PLS data. Table 3 and Figure 2 depict the CFA findings, whereas Table 5 and Figure 2 summarise the SEM findings.

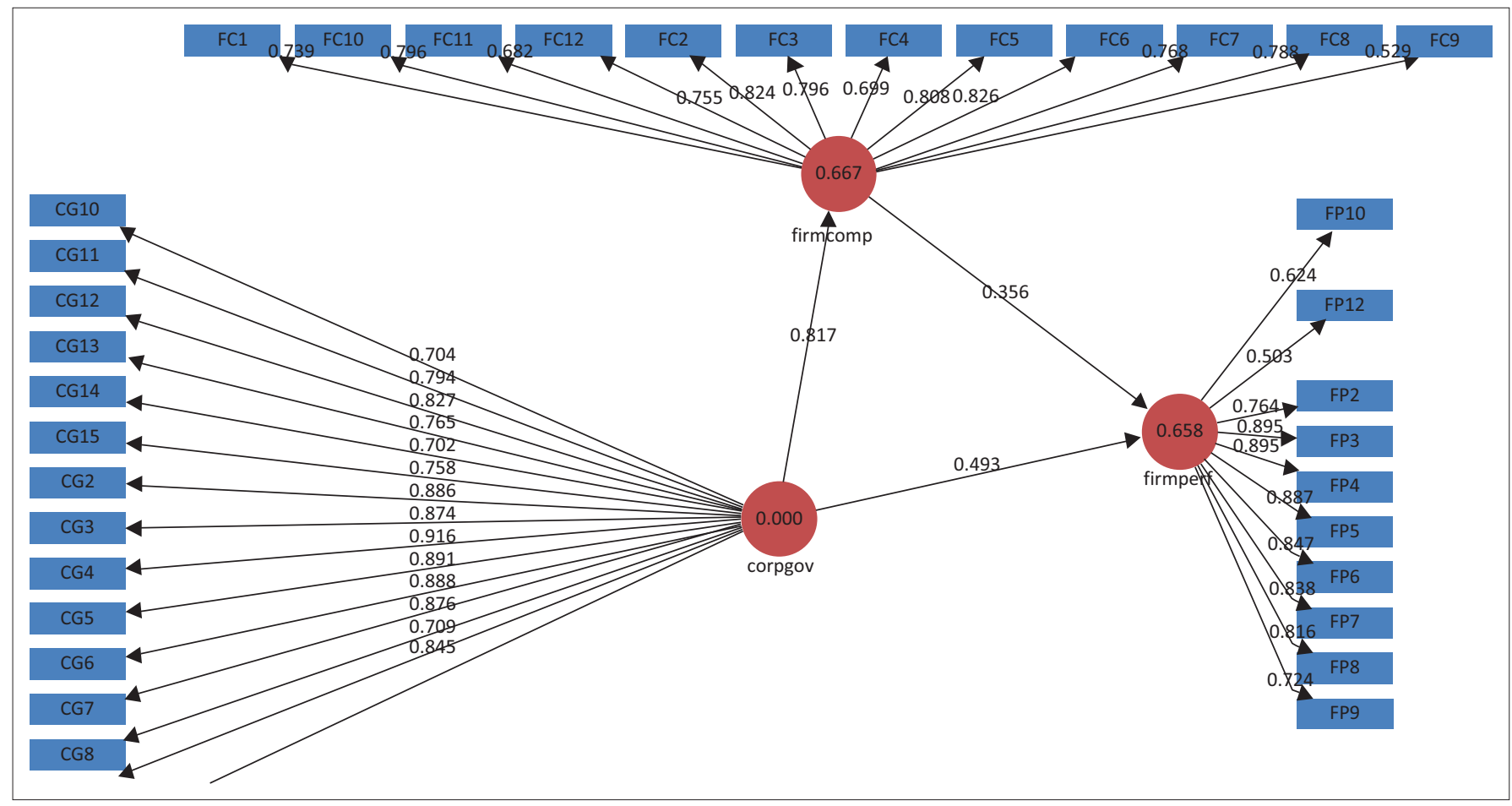

Source: Authors' own work

Corpgov, corporate governance; Firmcomp, firm competitiveness; Firmperf, firm performance.

$\mathrm{CG}$, corporate governance; $\mathrm{FC}$, firm competitiveness; $\mathrm{FP}$, firm performance.

FIGURE 2: Measurement and structural model results. 
TABLE 5: Results of structural equation model analysis.

\begin{tabular}{lcccc}
\hline $\begin{array}{l}\text { Proposed hypothesis } \\
\text { relationship }\end{array}$ & Hypothesis & $\begin{array}{c}\text { Path } \\
\text { coefficients }\end{array}$ & T-statistics & $\begin{array}{l}\text { Rejected or } \\
\text { supported }\end{array}$ \\
\hline CG $\rightarrow$ FP & H1 & 0.493 & 3.569 & Supported \\
CG $\rightarrow$ FC & H2 & 0.817 & 25.124 & Supported \\
FC $\rightarrow$ FP & H3 & 0.356 & 2.750 & Supported \\
\hline
\end{tabular}

Source: Authors' own work

$\mathrm{CG}$, corporate governance; $\mathrm{FC}$, firm competitiveness; FP, firm performance.

H1: Corporate governance has a positive impact on SMEs firm performance.

The present research study envisaged that theimplementation of corporate governance as a distinctive firm capability positively and significantly relates with the performance of SMEs. According to Figure 2 and Table 5 the SEM results shown give evidence whether the envisaged relationship is valid. Figure 2 shows 0.493 path coefficient for the hypothesised direct relatedness of corporate governance and firm performance. The path coefficient of 0.493 is bigger than the commended level of 0.2 and thereby confirming the supposed positive influence corporate governance has on firm performance of SMEs. A $t$-test was also carried out for the hypothesised correlation between corporate governance and firm performance of SMEs and a result of 3.569 was obtained as shown in Table 5. The T-statistic of 3.569 is above the acceptable level of 2.0 (Chinomona 2013), thus signifying that corporate governance adoption and compliance with corporate governance principles by SMEs significantly and positively influence their firm performance of SMEs. In the light of this, the depicted values in Table 5 and Figure 2 substantiate $\mathrm{H}_{1}$ on the grounds that the two standards of significance and positive path coefficient have been satisfied. As hypothesised, the results to this research indicate that the adoption and compliance with corporate governance principles by SMEs can enhance their firm performance. Such results are inconsistent with the common wisdom that small firms shy away from any corporate governance practices because of their lack of financial resources required. However, these findings confirm the findings of previous studies like Abor and Quartey (2010), which reported that SMEs' corporate governance when effectively practised improves the performance of the firm and attracts new investors. Consequently, this article firmly validates and agrees that corporate governance positively influences firm performance of SMEs.

\section{H2: Corporate governance positively influences SMEs} competitiveness.

This study also posited an important and positive influence corporate governance has on SMEs' competitiveness. As previously noted, the SEM was employed to test the existence of the hypothesised relationship and the results are depicted in Figure 2 and Table 5. In Figure 2, a coefficient of 0.817 is shown for the supposed direct relationship between corporate governance and firm competitiveness. This is above the acceptable threshold, thus evidencing the envisaged positive influence of corporate governance on SMEs' competitiveness. Table 5 shows a $t$-test result of 25.124 for the hypothesised correlation between corporate governance and SMEs' competitiveness. Again, the $t$-test result (25.124) is bigger than the acceptable standard of 2.0. This signifies that the adoption and compliance with the corporate governance practices and principles significantly and positively impact SMEs' competitiveness. Therefore, the summarised results support $\mathrm{H}_{2}$. The results obtained imply that the adoption and compliance with corporate governance principles as a distinctive firm capability by SMEs give them a competitive edge as they attract new investors and improve their competitiveness as a firm. Subsequently, this article significantly agrees that corporate governance positively influences firm competitiveness of SMEs.

H3: Firm competitiveness does positively impact SMEs' firm performance.

Furthermore, this study conjectured that firm competitiveness positively and significantly predicts SMEs' performance. As is presented in Figure 2, the hypothesised relationship between firm competitiveness and firm performance of SMEs yielded a positive path coefficient of 0.356 . This value (0.356) is above the standard acceptable and commended path coefficient of 0.2 , thereby evidencing that firm competitiveness positively impacts firm performance of SMEs. Following, as shown in Table 5, the $t$-test result of 2.750 further confirms the positive path coefficient shown in Figure 2 because it is also above the acceptable standard of 2.0. The implication here is that firm competitiveness does have a significant and positive influence on firm performance of SMEs. Despite being relatively, the obtained results agree with studies that have been done before which report the positive impact of a firm's competitiveness on its firm performance (Hove 2012). Hence, this writing confirms and agrees with the position that an $S M E^{\prime} s$ competitiveness positively influences their performance.

\section{Conclusions and implications}

This study has the following theoretical implications: firstly, the study provides a tested research model on how the adoption of corporate governance principles influences firm competitiveness and SME performance in Gauteng, South Africa. This model will serve as a guide for further research on South African SMEs' corporate governance principles adoption and how it impacts firm competitiveness and SME performance. This is especially key because there is currently a dearth of literature that focuses on SME corporate governance in the South African context. Thus, this study contributes significantly towards the body of literature in SME corporate governance. The empirical analysis of this study can be used for further research in other emerging contexts and can also be used in teaching, as well as influences public policies on SMEs and corporate governance compliance. The findings of this study also have practical implications as discussed below.

The evidence supporting the hypothesis that posited that corporate governance positively influences firm performance (H1) advises researchers to recommend that more SMEs 
should consider complying with the King Reports III and IV on corporate governance practices and standards, to capture the benefit of new investor attraction and improved performance. This can help improve the survival and growth of SMEs that have been reported to have a high failure rate in South Africa (Fatoki \& Garwe 2010). In fact, SME owners or managers should consider incorporating the applicable corporate governance principles in their missions, and core values of the firm, to serve as a reminder to all employees on these principles when performing duties and also help build a unique corporate culture on corporate governance. With the summarised corporate governance principles given in the King Report IV, as well as the clear distinction made between principles and practices in the new King Report, SMEs should adopt the principles that apply to them and implement them for good corporate governance, which will ultimately enhance their SME performance.

The study has also hypothesised that corporate governance positively influences SME firm competitiveness (H2), and the performed relevant tests confirmed the hypothesis. Based on the findings, the study recommends that the government and other SME developmental organisations formulate corporate governance standards and principles that are exclusive to SMEs in order to improve compliance. This will help create a competitive edge for these SMEs, improve their competitiveness and enhance their growth and sustainability in the long run. In addition, SME owners or managers need to be trained and educated about the importance of conforming with corporate governance traditions and principles. This can be done through running SME corporate governance workshops and even conferences to provide adequate training. For instance, there is a training institution (Global Business School of Entrepreneurship) established to promote corporate governance awareness in SMEs. This article recommends that the business school be utilised to conduct workshops and organise corporate governance conferences where SMEs can learn from those SMEs that have successfully complied with corporate governance and grew from it. The government may need to create a corporate governance fund specifically set aside for those SMEs that find it costly to practise corporate governance. The fund can also be used to subsidise the workshop and conference training costs to all the SMEs in financial need.

\section{Limitations and future research direction}

While this article generates important additions to academia and corporate practice, this study has limitations. Firstly, the present study was restricted to Vanderbijlpark, situated in the Gauteng Province of South Africa. Therefore, future studies may replicate the study focusing on other geographical areas of the country for results comparisons and generalisability. Furthermore, this article left a gap on investigating the mediating effect that firm competitiveness has on the relationship between corporate governance and firm performance in SMEs. Future studies can consider exploring the mediating role of firm competitiveness in the relationship between corporate governance and firm performance in SMEs. In addition, future research ought to emphasise on other non-financial constructs that may influence performance and competitiveness and how these relate to the practising of corporate governance in SMEs.

\section{Acknowledgements}

The authors would like to acknowledge the SME owners and the reviewers for their inputs.

\section{Competing interests}

We do hereby declare that there is no conflict of interest and that this article was only submitted to ACTA Commercii for review and publication.

\section{Authors' contributions}

P.H.S. was the project leader and was responsible for conceptualisation and research methodology. K.S. performed literature review and contributed to the write-up of the manuscript. D.P. guided on the direction of the manuscript and also contributed towards the write-up of the manuscript and edited the work.

\section{References}

Abor, J. \& Biekpe, N., 2007, 'Corporate governance, ownership structure and performance of SMEs in Ghana: Implications for financing operations', Corporate Governance 7(3), 288-300. https://doi.org/10.1108/14720700710756562

Abor, J. \& Quartey, P., 2010, 'Issues in SME development in Ghana and South Africa', International Journal of Finance and Economics 39, 218-228.

Anderson, J.C. \& Gerbing, D.W., 1988, 'Structural equation modelling in practice: A review and recommended two step approach', Psychological Bulletin 103(3), 411-423. https://doi.org/10.1037/0033-2909.103.3.411

Ansong, A., 2015, 'Board size, intensity of board activity and financial performance of SMEs: Examining the mediating roles of access to capital and firm reputation' Journal of Entrepreneurship and Business 3(2), 26-41. https://doi.org/10.17687/ JEB.0302.03

Arosa, B., Iturralde, T. \& Maseda, M., 2013, 'The board structure and firm performance in SMEs: Evidence from Spain', Investigaciones Europeas de Direccion y Economid de la Empresa 19, 127-135. https://doi.org/10.1016/j.iedee.2012.12.003

Bates, C., 2013, 'Governance in SMEs: Moving beyond red tape', viewed 30 April 2014, from http://www.entrepreneur.co.za

Badenhorst-Weiss, J.A., van Biljon, E.H.B. \& Ambe, I.M., 2017, Supply chain management: A balanced approach, 2nd edn., Van Schaik Publishers, Pretoria.

Byrne, B.M., 2001, Structural equation modeling with AMOS: Basic concepts, applications, and programming, Lawrence Erlbaum Associates, Publishers, Mahwah, NJ.

Cant, M., Gerber-Nel, C., Nel, D. \& Kotze, T., 2003, Marketing research, New Africa Books (Pty) Ltd, Cleremont.

CGF Research Institute, 2013, Corporate governance boost for SME in South Africa and SADC region, viewed 14 April 2014, from http://membersproudlysa.co.za

Chin, W.W., 1998, 'Issues and opinion on structural equation modelling', MIS Quarterly 22(1), 7-16.

Chinomona, R., 2013, 'Dealers' legitimate power and relationship quality in Gaunx distribution channel: A social rule system theory perspective', Internationa Journal of Marketing Studies 5(1), 25-74. https://doi.org/10.5539/ijms.v5n1p42

Claessens, S. \& Yurtoglu, B.B., 2013, 'Corporate governance in emerging markets: A survey', Emerging Markets Review 15, 1-33. https://doi.org/10.1016/j.ememar. 2012.03.002

De wit, B. \& Meyer, R., 2005, Strategy synthesis: Resolving strategy paradoxes to create competitive advantage, South-Western Cengage Learning, London.

Ehlers, T. \& Lazenzby, K., 2007, Strategic management: Southern African concepts and cases, 2nd edn., Van Schaik Publishers, Pretoria.

Fatoki, O.O. \& Garwe, D., 2010, 'Obstacles to the growth of new SMEs in South Africa: A principal component analysis approach', African Journal of Business Management 4, 729-738.

Flowers, D., Parker, H., Arenz, J., Gaffley, J., Greighton, L., Fredricks, L. et al.., 2013, 'An exploratory study on corporate governance for practices in Small and Micro fast moving consumer goods enterprises in Cape Metropole, Western Cape, South Africa', African Journal of Business Management 7(22), 2119-2125. 
Fornell, C. \& Larcker, D.F., 1981, 'Evaluating structural equation models with unobservable variables and measurement error', Journal of Marketing Research 27, 39-50. https://doi.org/10.2307/3151312

Fuenzalida, D., Mongrut, S., Arteaga, J.R. \& Erausquin, A., 2013, 'Good corporate governance: Does it pay in Peru?', Journal of Business Research 66, 1759-1770. https://doi.org/10.1016/j.jbusres.2013.01.008

Global Entrepreneurship Monitoring (GEM) Report, 2015/16 Global Report. Global Entrepreneurship Research Association (GERA), Portugal.

Hearn, B., 2011, 'The impact of corporate governance measures on the performance of West African IPO firms', Emerging Markets Review 12, 130-151. https://doi. org/10.1016/j.ememar.2011.02.004

Homburg, C. \& Pflesser, C., 2003, 'A multiple-layer model of market-orientated organizational culture: Measurement issues and performance outcomes', Journa of Marketing Research 37, 449-462. https://doi.org/10.1509/jmkr.37.4.449.18786

Hooley, G.J., Greenley, G., Cadogan, J. \& Fahy, J., 2005, 'The performance impact of marketing resources', Journal of Business Research 58(1), 18-27. https://doi. org/10.1016/S0148-2963(03)00109-7

Hove, P., 2012, 'The impact of technological marketing on Porter's competitive forces model and SMEs' performance', Unpublished dissertation, University of Fort Hare.

Hove, P. \& Chikungwa, T., 2013, 'Internal factors affecting the successful growth and survival of small and micro agri-business firms in Alice communal area', Journal of Economics 4(1), 57-67.

lacobucci, D. \& Churchill, G.A. (Jr.), 2010, Marketing research methodological foundations, 10th edn., South Western, Cengage Learning, Mason, Ohio.

Joreskog, K. \& Sorbom, D., 2006, LISREL 8.50, Scientific Software International Inc., Chicago, IL.

Kim, E.H. \& Lu, Y., 2013, 'Corporate governance reforms around the world and crossborder acquisitions', Journal of Corporate Finance 22, 236-253. https://doi. org/10.1016/j.jcorpfin.2013.05.005

Kim, W., Sung, T. \& Wei, S.J., 2017, 'The diffusion of corporate governance to emerging markets: Evaluating two dimensions of investor heterogeneity', Journal of International Money and Finance 70, 406-432. https://doi.org/10.1016/j. jimonfin.2016.10.002

King Report IV, 2016, Report on corporate governance for South Africa, Institute of Directors Southern Africa, Sandton.

Le Roux, F., 2010, 'The applicability of the third king report on corporate governance to SMEs', Unpublished dissertation, Stellenbosch University.

Liljander, V., Polsa, P. \& Van Riel, A., 2009, 'Modelling consumer responses to an apparel store brand: Store image as a risk reducer', Journal of Retailing and Consumer Services 16, 281-290. https://doi.org/10.1016/j.jretconser.2009. 02.005

Louw, L. \& Venter, P., 2010, Strategic management: Developing sustainability in Southern Africa, Oxford University Press, Cape Town.

Mangena, M. \& Chamisa, E., 2008, 'Corporate governance and incidences of listing suspension by the JSE securities exchange of South Africa: An empirical analysis', The International Journal of Accounting 43, 28-44. https://doi.org/10.1016/j. intacc.2008.01.002

Maniak, G., 2006, Determinants of competitiveness of firms, Working paper, University of Szczecin, Poland, Szczecin.

Melville, N., Kraemer, K. \& Gurbaxani, V., 2004, 'Information technology and organisational performance: An integrative model of IT business value', MIS Quarterly 28(2), 283-322.
Molokwu, V.B., Barreria, J. \& Urban, B., 2013, 'Entrepreneurial orientation and corporate governance structures at the firm level in South African oil and gas industry', South African Journal of Human Resources Management/SA Tydskrif vir industry', South African Journal of Human
Menslikehulpbronbestuur 11(1), 443-458.

Munisi, G., Hermes, N. \& Randoy, T., 2014, 'Corporate boards and ownership structure: Evidence from sub Saharan Africa', International Business Review 20, 785-796. https://doi.org/10.1016/j.ibusrev.2013.12.001

Muniandy, B. \& Hillier, J., 2015, 'Board independence, investment opportunity set and performance of South African firms', Pacific-Basin Finance Journal 35, 108-124. https://doi.org/10.1016/j.pacfin.2014.11.003

Neneh, N. \& Van Zyl, J., 2012, 'Achieving optimal business performance through business practices: Evidence from SMEs in selected areas in South Africa', Southern African Review 16(3), 118-144.

Ngobo, P.V. \& Fouda, M., 2012, 'Is good corporate governance good for business? A cross-national analysis of firms in African countries', Journal of World Business 47, 435-449. https://doi.org/10.1016/j.jwb.2011.05.010

Ntim, C.G., Lindop, S. \& Thomas, D.A., 2013, 'Corporate governance and risk reporting in South Africa: A study of corporate risk disclosures in the pre- and post 2007/2008 global financial crisis periods', International Review of Financia Analysis 30, 363-383. https://doi.org/10.1016/j.irfa.2013.07.001

Nunnally, J.C. \& Bernstein, I., 1994, Psychometric theory, 3rd edn., McGraw-Hill, New York.

Olawale, F. \& Garwe, D., 2010, 'Obstacles to the growth of new SMEs in South Africa: A principal component analysis approach', African Journal of Business Management 4(5), 729-738.

Pienaar, W.J. \& Vogt, J.J., 2012, Business logistics management: A value chain perspective, Oxford University Press, Cape Town.

Spanos, Y.E. \& Lioukas, S., 2001, 'An examination into the logic of rent generation: Contrasting Porter's competitive strategy framework and the resource-based perspective', Strategic Management Journal 22(10), 907-934. https://doi.org/ 10.1002/smj.174

Rossouw, G.T., van der Watt, A. \& Malan-Rossouw, D.P., 2002, 'Corporate governance in South Africa', Journal of Business Ethics 37(3), 289-302.

Sultan, S.S., 2007, The competitive advantage of small and medium sized enterprises: The case of Jordan's natural stone industry, Unpublished dissertation, Maastricht University.

Tenenhaus, M., Amato, S. \& Vinzi, V., 2004, 'A global goodness-of-fit index for PLS structural equation modeling', in Proceedings of the XLII SIS scientific meeting, pp. 739-742, CLEUP, Padova, France, Oral communication to PLS club, HEC School of Management.

Vorhies, D. \& Morgan, N., 2005, 'Benchmarking marketing capabilities for sustainable competitive advantage', Journal of Marketing 69(1), 80-94. https://doi.org/ 10.1509/jmkg.69.1.80.55505

Wetzels, M., Odekerken-Schroder, G. \& Van Oppen, C., 2009, 'Using PLS path modeling for assessing hierarchical construct models: Guidelines and empirical illustration', Management Information Systems Quarterly 33(1), 177-195.

Willan, C.L., Couchman, P.K., Sohal, A. \& Zutshi, A., 2016, 'Exploring differences between smaller and larger organizations' corporate governance of information technology', International Journal of Accounting Information Systems 22, 6-25. https://doi.org/10.1016/j.accinf.2016.07.002

Wong, H. \& Merrilees, B., 2007, 'Multiple roles for branding in international marketing', International Marketing Review 24(4), 384-408. https://doi. org/10.1108/02651330710760982 


\section{Appendix 1}

TABLE 1-A1: Firm performance measures.

\begin{tabular}{lll}
\hline Variable & PLS code & \\
\hline Exportation & FP1 \\
Sales growth & FP2 \\
Profitability & FP3 \\
\hline Employee satisfaction & FP4 \\
Employee retention & FP5 \\
Employee productivity & FP6 \\
Cost reduction & FP7 \\
Return on investment & FP8 \\
Customer satisfaction & FP9 \\
Customer retention & FP10 \\
New product development & FP11 \\
Innovation and learning & FP12 \\
\hline
\end{tabular}

Source: Authors' own work

PLS, partial least squares.

TABLE 2-A1: Corporate governance measures.

Variable/measure

PLS code

Complying with ethical leadership and corporate citizenship has given us a competitive edge.

CG1

Complying with ethical leadership and corporate citizenship has improved our overall firm performance.

CG2

Having an audit committee and external auditing has improved our competitiveness in the market.

Having an audit committee and external auditing has improved our overall performance.

Having a risk governance structure has given us a competitive edge over our rivals.

Having a governance structure has improved our overall performance.

Complying with internal auditing has improved our competitiveness in the market.

Complying with internal auditing has improved our overall firm performance.

CG6

CG7

Complying with stakeholder management has improved our competitiveness in the market.

Complying with stakeholder management has improved our overall firm performance.

CG8

CG9

Having an IT governance structure has made us unique and enabled us to differentiate our products.

CG10

Having an IT governance structure has improved our overall firm performance.

Complying with integrated reporting has improved our competitiveness in the market.

Complying with integrated reporting has improved our overall firm performance.

CG13

Compliance with laws, codes and standards that meet SME needs has improved our overall performance.

PLS, partial least squares. 